\title{
The Effect of Vlogging on Year 5 ESL Students' Speaking Performance
}

\author{
Xiu-Wei Chen ${ }^{1}$, Harwati Hashim ${ }^{2 *}$ \\ ${ }^{1} \mathrm{SJK}(\mathrm{C})$ Malayan, Ayer Hitam, Malaysia \\ ${ }^{2}$ Faculty of Education, Universiti Kebangsaan Malaysia, Bangi, Malaysia \\ Email: ^harwati@ukm.edu.my
}

How to cite this paper: Chen, X.-W., \& Hashim, H. (2022). The Effect of Vlogging on Year 5 ESL Students' Speaking Performance. Creative Education, 13, 698-716. https://doi.org/10.4236/ce.2022.132044

Received: January 12, 2022

Accepted: February 25, 2022

Published: February 28, 2022

Copyright $\odot 2022$ by author(s) and Scientific Research Publishing Inc. This work is licensed under the Creative Commons Attribution International License (CC BY 4.0).

http://creativecommons.org/licenses/by/4.0/

\begin{abstract}
Speaking skill among English for Second Language (ESL) students has always been a concern yet it has been neglected in ESL classrooms. With the increasing integration of technology in the classrooms and the overwhelming interest of students in social media, it is believed that vlogging, which is a process of creating vlog, is able to make lessons more engaging and interesting, and even improve students' speaking skills. This research reviews some past studies done on the effectiveness of vlogging in speaking skills and they evidenced that vlogging was indeed effective. However, there is very little research conducted in Malaysia and none was conducted for primary ESL students. Therefore, this study aims to explore how much vlogging helps in improving ESL Year 5 students' speaking performance. A total of 15 students from a rural primary school were selected through convenience sampling method. The study was conducted qualitatively and the participants' vlogs were analyzed thematically. Based on the data collected, it was found that the participants show improvement in terms of grammar, content, fluency and vocabulary but pronunciation was still a challenge for them. Therefore, it is hoped that this research could serve as a stepping-stone for vlogging being used as an effective way to improve students' speaking performance. In conclusion, this research proposes a new alternative in teaching speaking during ESL lessons.
\end{abstract}

\section{Keywords}

Vlogging, Speaking Performance, Primary Students, ESL, Technology-Enhanced Language Learning

\section{Introduction}

In this era of globalisation, English as the lingua franca is widely used across the 
globe as a means of verbal and written communication worldwide in different industries for economic, political and social purposes (Wong \& Md Yunus, 2021). In fact, English has transcended beyond practical uses, looking into the development of creativity (Ismail et al., 2019) that comes with different challenges such as reader reception (Haja Mohaideen et al., 2020). Speaking is considered as the most important skill. Due to the high intensity of interactions among people, there is a tremendous need for one to be able to communicate in a global language which is English. However, it is complicated for ESL students whose mother tongue is not English.

Speaking skill has always been a problem to many Malaysian students (Tunku Mohtar \& Swaran Singh, 2015). This problem was proven by a report that claims that students excelled in written English but failed at interviews (Rodriges, 2006). Over a decade, the same problem still exists and speaking is still a concern of many stakeholders as Selan (2021) stated that our school system may produce students who can write in English but to speak in English is totally different. This is shown by the decline in the results of EF English Proficiency Index where Malaysia was placed 9 of 40 countries in 2011, but after a decade, Malaysia is now positioned in the $28^{\text {th }}$ out of 112 countries (EF Education, 2022). Besides being a second language user, there are some problems that influence the teaching and learning of speaking. Since teaching and practising are time consuming, students generally have less involvement in speaking activities and teachers also less focus on enhancing speaking activities (Mandasari \& Aminatun, 2019). On top of that, some students are reluctant to speak because of their personal emotions such as being afraid of making mistakes and having low confidence to speak in front of people (Wulandari, 2019). Other challenges that might be faced while learning speaking are speaking anxiety, limited background knowledge, low participation and mother tongue use (Tuan \& Mai, 2015). When students encounter these problems, their motivation level would decrease, and hence speaking appears to be more challenging for them.

Due to the challenges mentioned above, it is significant to implement appropriate and suitable teaching techniques in the class in order to improve students' speaking skill. Therefore, teachers should conduct lessons which are more engaging and interesting to gain students' interest in learning to speak. Interesting media can be used to attract and motivate students to increase their confidence to speak English (Wulandari, 2019). Since the newest students who are also known as Gen-Z or Net Generation have different characteristics and learning expectations (Hashim, 2018), the teaching and learning of ESL has experienced major changes over the decades. As compared to traditional teaching and learning styles, the role of technology cannot be ignored in an English as Second Language (ESL) classroom in this 21 st century. Technology is said to have a positive impact on students' attitudes towards language teaching and learning as stated by Govindasamy et al. (2019) where it can be used as a motivational tool for learners in education. Students are more motivated to learn and have higher self-confidence and self-esteem as technology allows the students to take control 
over their own learning (Rahmawati et al., 2018).

In this $21^{\text {st }}$ century comes the leading technology innovation used as technological media in teaching and learning speaking, which is known as vlog. According to Nada (2021), a vlog combies images, audio, movies and text to personal reflections, expression of feelings, documentaries and stories. Vlogging, which refers to the process of recording a vlog, is usually done by vloggers speaking in front of a camera to share their opinions, thoughts or experiences. Vlogging is one of effective ways that can be used as a means to improve students' speaking ability because it emphasizes on speaking for its way of communication (Wulandari, 2019).

Speaking is an important skill to be mastered for the aim of communicating with the world community or dealing with their studies or professions. However, there are limited studies that focus on effectiveness of vlogging for primary students conducted in Malaysia. Therefore, the research was aimed to identify whether vlogging helps year 5 students in improving their speaking skills. The research question is outlined as below:

1) To what extent does vlogging affect Year 5 ESL students' speaking performance?

It is expected to enrich the information on the use of vlogging in learning speaking or perhaps shed some light on a different way in teaching speaking.

\section{Literature Review}

\subsection{Speaking Skill}

Speaking is one of the most important skills that determine one's proficiency level yet it is also not an easy skill to learn. Speaking is the ability to use speech to express or exchange thoughts through a language (Mart, 2012). Therefore, it is important for students to be able to speak as it allows them to interact with others and to express themselves clearly. According to Nunan (1989), speaking is the use of productive skill that consists of producing systematic verbal utterance in conveying the meaning.

Despite the importance of speaking, students find it difficult to learn speaking. Tuan and Mai (2015) stated some factors that could have influenced students' speaking performance, namely performance conditions which include time, planning, standard of performance and the amount of support given, affective factors such as motivation, confidence and anxiety level as well as students' listening ability and the feedback received during speaking activities. Another external factor that makes learning speaking difficult is the speaking environment (Abdul Samat et al., 2019). Speaking environment plays an important role as students will have more opportunities to speak the language.

\subsection{Integration of Technology in Teaching Speaking}

Due to the problems faced in learning speaking, technology should be integrated in the teaching and learning process. The white canvas of language teaching and 
learning has experienced major changes over the decade and emerged into a new era of education and technology (Pazilah et al., 2019). Technology does not do magic, but it certainly is a powerful tool that contributes to a positive impact in education by influencing students' way of learning (Aziz et al., 2019). It has also been mentioned by Mandasari and Aminatun (2019) that integration of technology into the teaching and learning process is one of the most effective ways to improve students' general performance.

There are a number of benefits discussed by researchers. Integrating technology allows teachers to give immediate feedback, promotes interaction through active participation (Dedo \& Hashim, 2019) as well as personalises learning according to individual differences (Hashim et al., 2017). Some other advantages that integrating technology in teaching and learning offers are providing a more comfortable and convenient learning environment, promoting peer coaching, enhancing social skills and increasing students' enthusiasm and self-confidence to learn ESL skills (Abdul Halim \& Hashim, 2019).

By bringing in the element of technology which the new generation is great at, students are given opportunities to have discussion outside the classroom to form a sense of community. Creating a sense of community in an online environment is important because students always do not have enough interactions with each other in the classroom due to limited time (Abdul Halim \& Hashim, 2019). Besides that, a more student-centered learning environment can be created by integrating technology in the teaching and learning. Student-centered learning environment needs students to participate and be involved in the learning process actively (Brandes \& Ginnis, 1986). Video blogging, which is commonly abbreviated as vlogging, is said to encourage self-monitored speaking (Watkins, 2012) where students need to be very clear of what they are doing and take control over the learning process.

\subsection{The Use of Vlogging in Teaching Speaking}

Kurniawan and Susanti (2019) noted that most students can only practise English in class which is very limited. Vlogs increases the possibility for students to practise spoken production skills as recommended by the Common European Framework Reference for languages (Combe \& Codreanu, 2016). It gives students an opportunity to use the language in an authentic context of communication outside the classroom. By using the language frequently, it definitely also increases students' confidence in speaking. Besides that, there are more advantages of vlogging that are discussed. Mandasari and Aminatun (2019) conducted research on vlogging and found that vlogging improves language learning process, making language learning interesting and also increasing students' motivation in learning. On top of that, their research findings reveal that the majority of the students had better understanding towards English materials.

The bright impact of vlogging could be the results from the process of creating vlogs. There are chronological steps as suggested by Sun (2009) for implementation of vlogging in teaching and learning, namely conceptualising, brainstorm- 
ing, articulation, monitoring and evaluating. Students are required to have a plan on the content of the topic given and brainstorm the content that they want to deliver. In this step, students are given the autonomy where they can choose and decide what they want to include in their vlogs. After that, students need to practise and do rehearsal before recording. In order to improve their speaking ability, adequate practice is one of the key factors. Students must not only have enough exposure to the language, but must also be given chances to use the language. This is supported by Watkins (2012) where he stated that vlogging increases students' talk time and more practice helps them to improve vocabulary and grammar, reduce shyness and boost their confidence as well as develop fluency.

While practising and recording, students need to monitor their vlogs. They have to be well aware of the suitability of content and the accuracy. Lastly, evaluation of vlogs is carried out. Students may do self-correction as well as ask for opinions and feedback from their peers or teachers. Based on the feedback given, students make improvements in their vlogs. Producing vlogs by referring to the steps above requires students to review and practise again and again.

\subsection{Past Related Studies on Vlogging}

There has been a lot of research conducted to investigate the effectiveness of vlogging in improving speaking skills. In most of the past studies, the findings reveal positive impacts on students' improvement in speaking skills. There was a recent research conducted by Nada (2021) to determine the effectiveness of using vlog towards the improvement of students' speaking skills through their recorded videos. It adopted quantitative and qualitative data collection methods. The researcher highlighted a few positive changes in students' speaking from the use of vlogging. In the research, more than half of the participants claimed that the use of vlogs motivated them in learning to speak, increased their academic performance, gained more opportunities to speak English and created an interactive learning environment. In terms of their speaking performance, the participants had improved their accuracy and fluency. This research finding is supported by a quasi-experimental research carried out by Kartini et al. (2021). The findings clearly showed that participants in control and experiment groups had different speaking proficiency where the experiment group had a mean score of 60.00 and control group had a mean score of 81.20. The results were evident that the implementation of vlogging was effective in improving students' speaking proficiency.

On top of that, in the research conducted by Marzuki and Nurpahmi (2019), the researchers found that the use of vlogging had improved students' speaking skills in terms of accuracy, pronunciation, grammar and vocabulary. This is in line with the data collected by Rahmawati et al. (2018). In their research, they did not only find improvement in speaking skills but also an observable improvement of students' activeness and interest in the learning process. It is also found that students became more confident in using the language. Despite the 
positive impacts of vlogging, most of the past studies were conducted for secondary and tertiary students in other countries. Therefore, the researchers intended to see the effectiveness of vlogging in improving speaking performance of primary school students.

\section{Research Method}

\subsection{Research Design}

The study adopted qualitative research to have an in-depth understanding of the topic. According to Creswell (2012), qualitative research is the best to address a research problem that the researcher needs to learn more about a central phenomenon through exploration. Rahi (2017) also stated that a qualitative research method is used to collect in-depth details of a particular topic and it assumes that a single person represents the group feelings and emotions of a person which are important to be interpreted. Therefore, it is believed that qualitative data is more useful in investigating the effectiveness of vlogging in improving Year 5 students' speaking performance as the researchers were able to gain personal information from the participants. The data for this research was obtained from the vlogs that the participants produced and it was analysed by using thematic analysis.

\subsection{Participants}

The research participants were selected through convenience sampling technique to enable the researchers to attain responses from the participants in a cost-effective way (Rahi, 2017). The participants of the research were a total of 15 students who are from a rural Chinese type national school located in Ayer Hitam in Southern Johor, Malaysia.

The academic performance of the participants was assessed based on school-based assessment and they were graded according to Performance Level, which is normally known as Tahap Penguasaan (TP). The Performance Level ranges from one (the lowest) to six (the highest). The selected participants have mix-ability in their English proficiency level, but majority of them (9 participants) are in the intermediate level which is TP 3 and TP 4. Their Performance Level is presented in Table 1 below.

Table 1. Participants' performance level.

\begin{tabular}{cc}
\hline Performance Level & Number of Participants \\
\hline TP1 & 0 \\
TP2 & 2 \\
TP3 & 4 \\
TP4 & 5 \\
TP5 & 4 \\
TP6 & 0 \\
\hline
\end{tabular}


Participants with different levels of proficiency were selected to ensure that there was no bias in the research findings and to figure out whether vlogging strategy is useful and effective for students with different proficiency levels. Besides that, this group of participants grew up in an entire Chinese speaking environment. They do not have an English-speaking background at home and their classmates are all Chinese. The only English exposure they have is during English lessons at school. Hence, the second reason why they were chosen as the target participants was because the researchers intended to investigate the effectiveness of vlogging on students from purely Chinese speaking backgrounds.

\subsection{Research Instrument}

Since this research was conducted qualitatively, audio-visual material was the instrument used. According to Creswell (2012), audio-visual materials are images or sounds that researchers collect to help them in understanding the central phenomenon of the study. In this research, the audio-visual material, which is the vlogs produced by the participants, is an important source of data for the researchers to identify the effectiveness of vlogging in improving speaking skills. The participants were requested to record four vlogs in total in two months' time. The requested amount of time for each vlog is two minutes and the participants were allowed to freely share anything they wanted in relation to the topics given.

The vlogs that the participants produced are solid evidence of their progress in speaking skill. As mentioned by Parmawati and Inayah (2019), speakers must pay attention to vocabulary, grammar and pronunciation. Therefore, their vlogs were being analysed based on a speaking rubrics which was adapted from Watkins (2012) and Mandasari and Aminatun (2019). There are five main elements to be emphasised when evaluating the vlogs which are grammar, content, fluency, pronunciation and vocabulary. The evaluative criteria are detailed in Table 2. The evaluative criteria worked as a determinant of how much the participants' speaking performance had improved from their first vlog to the last vlog.

\subsection{Research Procedure}

After problems were identified, the researchers set research objectives and reviewed literature. Then, the researchers identified suitable research design, data collection methods and data analysis methods. Since the participants were 11-year-old primary school students, the parents or guardians of the participants were requested to fill in the consent letter via Google Form before the research was conducted. This was to ensure that they were aware that the participants' faces or speeches might be quoted in the research. As mentioned by Elliott et al. (1999), researchers must gain informed consent and perform in an ethical manner such as respect participants' rights and protect their confidentiality and data. After getting consent from the parents, the research was carried out for a two-month period. 
Table 2. Evaluative criteria for vlogging.

\begin{tabular}{|c|c|}
\hline Proficiency Area & Evaluative Criteria \\
\hline \multirow[t]{4}{*}{ Grammar } & Good progress in grammar usage \\
\hline & Occurrence of same grammar mistakes \\
\hline & Students' ability to learn English \\
\hline & Meaning being discerning by grammar mistakes \\
\hline \multirow[t]{2}{*}{ Content } & Reach the requested amount of time \\
\hline & Talk based on the topics given \\
\hline \multirow[t]{2}{*}{ Fluency } & $\begin{array}{l}\text { Talk smoothly and confidently without interruption such as long } \\
\text { and awkward pauses }\end{array}$ \\
\hline & Talk spontaneously instead of reading from the script \\
\hline \multirow[t]{3}{*}{ Pronunciation } & Consistent pronunciation errors \\
\hline & Predictable pronunciation errors \\
\hline & Pronunciation is hard to understand \\
\hline \multirow[t]{2}{*}{ Vocabulary } & Correct and appropriate use of word \\
\hline & Suitable vocabulary for an academic audience \\
\hline
\end{tabular}

The participants were required to produce four vlogs in total every two weeks. The vlogs recorded were based on four given topics, namely "My Hobbies", "My Favourite Movie and Characters", "Food" and "A Trip". The researchers conducted a lesson before the participants recorded each vlog. In each lesson, the participants were taught on the ways to construct their ideas, tenses used and possible vocabulary which was related to the topic that they could use in their vlogs. There were a total of four lessons for four vlogs. The PowerPoint slides, as shown in Figure 1, were uploaded on Google Classroom for them to refer.

After each lesson, the participants were given one week to brainstorm and plan their draft. They were required to send their draft, some in the form of a mind map and some in point form, to the researchers and the researchers gave feedback based on the draft. The participants might have to add more information or correct their grammar mistakes before recording. After the participants had done recording their vlogs, they had to send their videos to the researchers. If it was necessary, the researchers gave feedback to the participants again and they had to record the video once again for better performance. Once the data was obtained, the researchers analysed and discussed the findings as well as completed the report.

\subsection{Research Analysis}

The data obtained were analysed qualitatively using thematic analysis that is a process of identifying patterns or themes within qualitative data, which organises and represents data in vibrant details (Mihăilescu, 2016). Al-Subaihi and Ismail (2020) stated that "an excellent thematic analysis interprets, describes and 
makes a full understanding of the collected data". For the purpose of this study, Braun and Clarke's (2006) six-phase framework for a thematic analysis, which is shown in Table 3, was used.

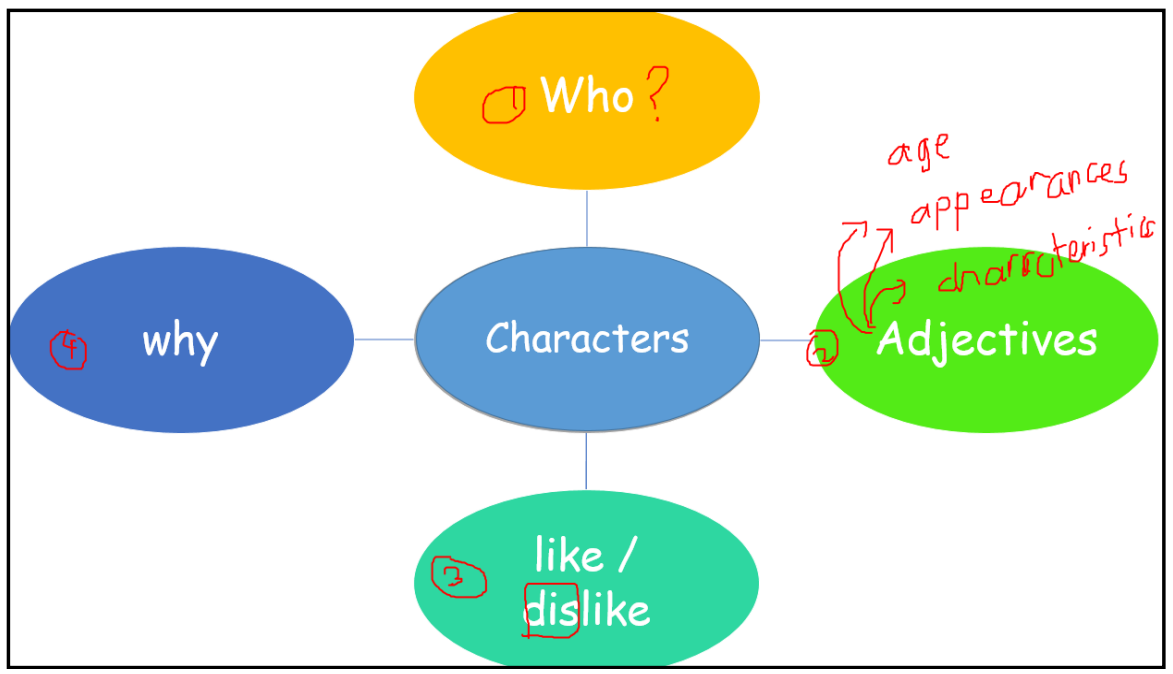

(a)

\section{Descrilibing Charcacters}

- characteristics

- strong / muscular

- funny

- rude

- cheeky / naughty

- brave

- loyal

- smart / wise / intelligent

- do not give up easily

(b)

Figure 1. PowerPoint of the lesson.

Table 3. Braun and Clarke's (2006) six-phase framework for a thematic analysis.

\begin{tabular}{cc}
\hline Step & Phase \\
1 & Becoming familiar with the data \\
2 & Generating initial codes \\
3 & Searching for themes \\
4 & Reviewing themes \\
5 & Defining themes \\
6 & Writing-up \\
\hline
\end{tabular}


In the first step, the research went through all the vlogs that the participants created to get familiar with the content. Then, the researchers organised the data to generate codes after going through the data. The researchers searched for suitable themes that answer the research questions. The themes were then reviewed and defined to ensure that the themes and the data matched. In the last step, the researchers completed the analysis write up.

\section{Findings and Discussion}

Grammar, content, fluency, pronunciation and vocabulary were chosen as important aspects to be evaluated as they play important roles in delivering accurate messages. Correct grammar used in speaking enables the listener to grab the content spoken more accurately. Content is equally important in vlogging as it shows participants' speaking ability if they have sufficient content and are able to speak for a certain period of time. Then, fluency is one's smoothness in continuing to speak spontaneously (Herlina, 2014). Pronunciation which refers to the articulation of words is vital as wrong pronunciation may lead to misunderstanding. Lastly, the vocabulary chose in speaking is also important as it enables the participants to convey messages and listener to understand accurately. Therefore, based on the vlogs produced by the participants, the results are discussed in terms of the aspects mentioned above.

\subsection{Grammar Mistakes Reduced}

Grammar plays an important role in speaking. It is a set of rules that describe the correct word order as well as the change of word forms (Harmer, 2001). It is noticed that mistakes in sentence structures used by the participants are slightly increased. Tenses used in explaining the topic is one of the most commonly seen mistakes. A number of participants did not use correct tenses in some of the sentences in their vlogs. Subject-verb agreement is another mistake made by most of the participants. Some of the participants did not add $-\mathrm{s}$ behind verbs after the subject "he", "she" and "it" whereas some participants used present tense and past tense wrongly. Some of the grammar mistakes were extracted and shown in Table 4.

Referring to Table 4, it is shown that tenses and subject-verb agreement mistakes were not much found in the last vlogs the students produced. Tenses used are important as it may change the meaning of the sentence. The most commonly used tenses in the vlogs were present tense and past tense. These two tenses show actions happened in the present and in the past, if it was wrongly used, confusion or misunderstanding may occur. For example, Participant P5 said "My family and I take the tram ..." which should be "My family and I took the tram ..." because she was referring to a trip in the past. Although there was only a word difference, it brings different meanings.

The reduction in grammar mistakes might be due to repetition and practice that participants did during the process of vlogging. This is in line with the 
Table 4. Grammar mistakes in the first and last vlogs.

\begin{tabular}{|c|c|c|}
\hline \multirow{2}{*}{ Participant } & \multicolumn{2}{|c|}{ Quotes from Participants' Vlogs } \\
\hline & First & Last \\
\hline \multirow[t]{3}{*}{$\mathrm{P} 3$} & “...grandfather will watching (watches) television..." & “...took a cruise for (to) see blue tear..." \\
\hline & "Every weekend, my father will play (plays) badminton with me." & “...took a lot of photos are there." \\
\hline & “...because COVID-19 come in (because of COVID-19)...” & \\
\hline \multirow[t]{6}{*}{ P5 } & "My mother teach (teaches) me how to..." & "When we entered into (entered) the zoo ..." \\
\hline & "Sometimes, I will play (play) duet with..." & “... excited to $\operatorname{saw}($ see $) .. . "$ \\
\hline & "She teach (teaches) ..." & "My family and I take (took) the tram ..." \\
\hline & "I like (to) play lego ..." & "It is (was) a really great show!" \\
\hline & "Sometimes, my younger brother will join (joins) me too!" & \\
\hline & "I hope you will enjoy (enjoy) watching..." & \\
\hline \multirow[t]{4}{*}{ P6 } & "I doing $($ do $)$ sports..." & "My trip is travelling (I travelled) to Melaka." \\
\hline & "I started doing sports because it was (is) fun." & "We go play (played) at the dinosaur garden ..." \\
\hline & “... it was (is) exciting ..." & "We gonna bought (bought) ticket ..." \\
\hline & $\begin{array}{l}\text { "I sometimes painting (paint) with my brother, sometimes } \\
\text { painting with my friends." }\end{array}$ & \\
\hline
\end{tabular}

statement of Tran and Nguyen (2019) where they mentioned that learners may master the language in different ways such as doing exercises, listening to audios or practising speaking on their own or with others. The mistakes found in the vlogs mostly did not change the meaning of their speech where most of the participants' vlogs were comprehensible. However, it is still important for the participants to enhance their grammar such as tenses, prepositions and sentence structures in order to be able to convey their messages clearly, communicate freely and talk naturally.

\subsection{Content Is Generally Adequate}

In terms of content, the participants were required to create a two-minute vlog for each topic assigned to them. As shown in Table 5, the participants generally were able to produce vlogs ranging from 1:30 minutes to 3:00 minutes. The longest over-time vlog lasts for 3:36 minutes, which was produced by Participant P2, and consisted of plenty of information. Participant P2 shared about his trip in detail while showing some pictures taken during the trip. He was able to explain with adjectives and made his vlog richer in terms of content.

According to Rahmah (2018), students need to have some background knowledge for their speaking when they want to produce words. All the participants attended a lesson before planning and recording each vlog, so they were guided with adequate background knowledge about the content that they were going to deliver. On top of that, they also drafted their ideas and sent them to the researchers for checking, received feedback and made amendments to ensure that the content was relatable. Therefore, all of them were able to talk based on the 
Table 5. Time of each vlog produced.

\begin{tabular}{ccccc}
\hline \multirow{2}{*}{ Participant } & \multicolumn{4}{c}{ Time (minutes) } \\
\cline { 2 - 5 } $\mathbf{1}^{\text {st }}$ Vlog & $2^{\text {nd }}$ Vlog & $3^{\text {rd }}$ Vlog & $4^{\text {th }}$ Vlog \\
\hline P1 & $2: 01$ & $1: 49$ & $1: 56$ & $2: 07$ \\
P2 & $1: 44$ & $2: 02$ & $2: 32$ & $3: 36$ \\
P3 & $1: 53$ & $2: 07$ & $1: 52$ & $1: 49$ \\
P4 & $1: 28$ & $1: 56$ & $1: 50$ & $1: 44$ \\
P5 & $1: 30$ & $3: 00$ & $1: 51$ & $2: 14$ \\
P6 & $2: 06$ & $1: 48$ & $1: 42$ & $1: 30$ \\
P7 & $2: 08$ & $1: 59$ & $1: 58$ & $2: 38$ \\
P8 & $1: 13$ & $1: 29$ & $1: 34$ & $1: 40$ \\
P9 & $1: 45$ & $2: 10$ & $1: 37$ & $1: 27$ \\
P10 & $1: 27$ & $1: 48$ & $1: 52$ & $2: 50$ \\
P11 & $1: 29$ & $1: 22$ & $1: 36$ & $1: 45$ \\
P12 & $1: 48$ & $1: 58$ & $1: 43$ & $1: 39$ \\
P13 & $2: 05$ & $2: 49$ & $2: 01$ & $1: 56$ \\
P14 & $1: 52$ & $2: 41$ & $2: 13$ & $2: 48$ \\
P15 & $2: 01$ & $1: 56$ & $1: 51$ & $1: 52$ \\
\hline
\end{tabular}

topics given. Basically, they had shared their experiences or views clearly.

Table 5 above shows that 11 participants showed an increase in the length of vlogs. However, four participants (P6, P8, P9 and P12) did not reach the required amount of time for their last vlogs. These participants had limited information and elaboration was lacking. For example, P6 mentioned “... We visited a dinosaur park ... saw a lot dinosaurs there, but those are fake ..." She only talked about where she visited, but did not elaborate more on what she did and describe the park. Participant P8 had the same issue, he said "... We did some sightseeing and visited some famous places ...” Participant P8 could have described the places they visited and shared any special events in his trip.

\subsection{Improvement in Fluency}

Fluency should be rioritized when it comes to learning a second language (Saputro, Tafsirudin, \& Farah, 2020). According to Fillmore (1979, as cited in Moradi \& Talebi, 2014), fluency refers to one's ability to speak at length with little pauses, express message coherently, know what to say in appropriate contexts as well as use the language creatively and imaginatively. There are two types of fluency, namely cognitive fluency and performance fluency. Segalowitz (2000, as cited in Shahini \& Shahamirian, 2021) defined cognitive fluency as "the efficiency of the operation of the cognitive mechanisms underlying performance" whereas performance fluency is "the observable speech, fluidity and accuracy of the 
original performance".

It is found that the participants sometimes paused for a long time and also kept repeating in an attempt to complete the sentence in the first vlogs. They repeated certain words or phrases as they doubted their pronunciation as well as their sentence structure. For instance, Participant P5 paused a few times in her vlog, such as "I also enjoy play... playing... play lego" and "So these are my ... these are ... these are the things I like to do." Participant P10 also had some pauses and repetitions in his first vlog "and I am no expetion ... expetions ... expetion (exception)" and "I have been re ... ri ... riding bicycle science ... since ... since I was five years old". Besides that, a few participants also remained silent in some parts of their vlogs and tried to look at their script. This finding is similar with the research findings by Nehe, Mayuni and Rahmat (2018) where they found that the participants often made a pause, made repetition of sentences frequently as well as thought to memorise the dialogue.

In the last vlogs the participants created, they had fewer pauses in their last vlogs and they were able to speak smoothly as they were getting used to the way of speaking. The slight improvement in fluency in this research is opposite from the data conducted by Saputro et al. (2020). It is believed that the improvement in fluency is due to repetition made during vlogging. While planning and recording vlogs, participants practised and repeated for a few times to get the best vlog they could produce. As supported by Shahini's and Shahamirian's (2021) research, the participants mentioned that repetition played a crucial role in achieving fluency in speaking. This is in accordance with Harmer's (2015) findings which he found repetition is important for speaking practice because learners gain extra chances to try speaking the language, refine their speech and also gain confidence in what they say. This is also coherent with the findings of this research, besides being able to speak more fluently, some of the participants also became more confident when speaking in front of the camera.

\subsection{Struggling for Correct Pronunciation}

After some practice and a number of recordings, it is still obvious that pronunciation was a challenge for most of the participants. Besides participants who were good at pronouncing English words (Participant P5, P6, P11, P13 and P14), improvement was hardly observed from other participants' vlogs. Among the pronunciation mistakes made by the participants, the confusion between $/ \mathrm{r} /$ and $/ \mathrm{l} /$ is the most serious where they tended to pronounce / $\mathrm{r} /$ as $/ \mathrm{l} /$. Regardless of the position of the $/ \mathrm{r} /$ sound, initial, medial or final position, some participants always pronounced it as /1/. This is not surprising as Wan Ibrahim, Kamarudin and Ramachandran (2007) had noted that most Chinese students who learn English have problems in differentiating the $/ \mathrm{r} /$ and $/ \mathrm{l} /$ sounds. Some words that were pronounced wrongly by participants are shown in Table 6 .

Apart from failing to pronounce / $r$ / sound, some participants had other problems in pronunciation such as adding or removing /s/ sound in the final position and pronouncing words with three or more syllables. Table 7 displays some 
wrong pronunciations made by the participants.

There was especially one participant P3 who had difficulties in pronouncing words. He seemed to use a lot of effort to complete even a sentence, yet, sometimes it was still not understandable. Most of his pronunciation mistakes were in the final position. Table 8 below shows pronunciation mistakes done repeatedly by Participant P3 throughout the four vlogs.

It was very noticeable that Participant P3 tried very hard in pronouncing the words correctly and he took it seriously. However, it seemed that he was quite pressured to speak or to utter the words correctly. Pronunciation was considered a major issue for the majority of the participants. In order to help the participants to speak at ease, pronunciation was definitely one of the obstacles that needs to be overcome. Abdul Aziz and Kashinathan (2021) also suggested providing activities that enhance students' pronunciation as it could help to reduce their fear of mispronouncing unfamiliar words.

\subsection{Appropriate Vocabulary Used}

The vocabulary used were mostly appropriate in the last vlogs the participants

Table 6. Words with /r/ that are mispronounced by participants.

\begin{tabular}{cccc}
\hline Participant & Word & Correct Pronunciation & Participants' Pronunciation \\
\hline P1 & parents & /'peərənt/ & /'peələnt/ \\
& sorry & /'sbri/ & /'svli/ \\
P3 & eyebrow & /'arbrav/ & /'arblav/ \\
& during & /'djoərın/ & /'djoəlın/ \\
& reading & /'ri:din/ & /'li:din/ \\
& storybook & /'sto:ribuk/ & /'sto:libuk/ \\
\hline
\end{tabular}

Table 7. Other mispronunciation made by participants.

\begin{tabular}{ccc}
\hline Word & Correct Pronunciation & Participants' Pronunciation \\
\hline comics & /'kbmiks/ & /'kbmı/ \\
because & /bı'kəz/ & /bı'kə/ \\
character & /'kærəktə(r)/ & /'kərəktə/ \\
favourite & /'fervərit/ & /'fævərət/ \\
interesting & /'intrəstı// & /'intərəstı// \\
\hline
\end{tabular}

Table 8. Pronunciation mistakes done by Participant P3.

\begin{tabular}{ccc}
\hline Word & Correct Pronunciation & Participant P3's Pronunciation \\
\hline am & /əm/ & /ən/ \\
share & $/$ eər/ & $/ \mathrm{fa}: /$ \\
watch & $/ \mathrm{wbt} / /$ & $/ \mathrm{wo}: \mathrm{ks} /$ \\
home & $/ \mathrm{hovm} /$ & $/ \mathrm{ho:l} /$ \\
\hline
\end{tabular}


created. Before each vlog was recorded, a lesson about grammar, content and vocabulary of the topic was conducted to ensure that the participants had enough background knowledge regarding the topic. The participants were also advised to jot down vocabulary that they might use in their vlogs. Therefore, it is found that the participants mostly referred to the PowerPoint slides given to look for suitable vocabulary to use in their vlogs. This clearly proved that sufficient guidance and background knowledge were equally important for students to improve in speaking performance. This is supported by Tuan \& Mai (2015) where they mentioned that lack of background knowledge is one of the factors that make it challenging to select appropriate vocabulary.

However, there were still times when the participants did not know some words in English. Therefore, the researchers observed that some participants tended to look up words or directly translate words on the internet via Google translate or other applications. The incorrect vocabulary used is presented in Table 9 below. It was indeed a positive sign where participants were willing to take the initiative to look up words, but it also created another problem in speaking due to the confusion of parts of speech. The parts of speech of some vocabulary used by participants in the sentences were incorrect because they simply searched for direct translation and did not pay attention to the parts of speech.

According to Rahmah (2018), being clear with parts of speech improves students' speaking ability, enriches their vocabulary and also helps them to communicate effectively. Despite the confusion on parts of speech, viewers basically are still able to understand the message that they want to deliver.

\section{Conclusion}

Speaking skill in sight of ESL students is challenging despite its importance. Hence, the research was conducted to identify whether vlogging helps year 5 students in improving their speaking skills. Based on the findings, it can be concluded that vlogging can be implemented in teaching and learning speaking for primary school students as this research shows that improvement is seen from students' first to their last vlogs. Teachers are recommended to teach speaking by integrating vlogging, asking students to create their own vlogs as in the process of producing vlogs, they have adequate time to practise to improve their speaking skills. To optimise the use of vlogging, teachers can also divide students into pairs or groups to allow them to have discussion and review their vlogs.

Table 9. Incorrect vocabulary used by participants.

\begin{tabular}{ccc}
\hline Participant & Incorrect & Correct \\
\hline P7 & “... and many beautiful painting & "... and many beautiful paintings." \\
P13 & "Painting can relax me." & "Painting is relaxing." \\
& “... and wide my imagination." & “... and expand my imagination." \\
\hline
\end{tabular}


Hence, vlogging does not only improve students' speaking skills but also boost their confidence and motivation. However, teachers must allocate enough time for students to complete a vlog and provide guidance along the journey of creating a vlog.

For students who would like to use vlogging to improve speaking performance, it is suggested that they should watch a lot of vlogs that other vloggers created to get an idea and learn how they arrange the flow, plan and deliver the content as well as edit vlogs. In addition, students should also draft their ideas and get familiar with the key points to be mentioned in vlogs. In order to really learn from vlogging, students are strongly advised to get assistance from teachers. They should send their draft and vlogs to their teachers to check in order to avoid mistakes and learn from their mistakes.

For future research, researchers could conduct this research by dividing the participants into groups according to their proficiency level as well as providing them different amounts of guidance and having different requirements from them. It is because some weak students who have very low proficiency level found it very difficult to speak for a longer period. They might need more time to create a vlog which may be shorter than intermediate or high proficiency level students. Therefore, it would be more helpful if the research is differentiated according to proficiency level to be helpful to the students. Besides that, it is recommended that researchers inquire more on teachers' points of views such as challenges in implementing vlogging or students' performance in the lessons so as to have another side of findings that can be discussed.

\section{Acknowledgements}

The authors would like to acknowledge Ministry of Higher Education Malaysia (MOHE) under the Fundamental Research Grant Scheme (FRGS) with project code no. FRGS/1/2019/SS09/UKM/02/2 for supporting this research and Universiti Kebangsaan Malaysia under research grant no. GG-2021-003.

\section{Conflicts of Interest}

The authors declare no conflicts of interest regarding the publication of this paper.

\section{References}

Abdul Aziz, A., \& Kashinathan, S. (2021). ESL learners' Challenges in Speaking English in Malaysian Classroom. International Journal of Academic Research in Progressive Education \& Development, 10, 983-991. https://doi.org/10.6007/IJARPED/v10-i2/10355

Abdul Halim, M. S. A., \& Hashim, H. (2019). Integrating Web 2.0 Technology in ESL Classroom: A Review on the Benefits and Barriers. Journal of Counseling and Educational Technology, 2, 19-26. https://doi.org/10.32698/0381

Abdul Samat, N. A., Muthu, S., \& Yunus, M. (2019). DULINGUISTIC Enhancing English Communication Skills among Malaysian Primary School Pupils. Creative Education, 
10, 48-58. https://doi.org/10.4236/ce.2019.101004

Al-Subaihi, A. N., \& Ismail, H. H. (2020). Orwell's 1984 and the Concept of Powerlessness. International Journal of English, Literature and Social Sciences, 5, 289-297. https://doi.org/10.22161/ijels.51.48

Aziz, N., Hashim, H., \& Yunus, M. M. (2019). Using Social Media to Enhance ESL Writing Skill among Gen-Z Learners. Creative Education, 10, 3020-3027. https://doi.org/10.4236/ce.2019.1012226

Brandes, D., \& Ginnis, P. (1986). A Guide to Student-centered Learning. Black Well.

Braun, V., \& Clarke, V. (2006). Using Thematic Analysis in Psychology. Qualitative Research in Psychology, 3, 77-101. https://doi.org/10.1191/1478088706qp063oa

Combe, C., \& Condreanu, T. (2016). Vlogging: A New Channel for Language Learning and Intercultural Exchanges. In S. Papadima-Sophocleous, L. Bradley, \& S. Thouesny (Eds.), CALL Communities and Culture-Short Papers from EUROCALL 2016 (pp. 119-124). Research-publishing.net https://doi.org/10.14705/rpnet.2016.eurocall2016.548

Creswell, J. W. (2012). Educational Research: Planning, Conducting and Evaluating Quantitative and Qualitative Research. Pearson.

Dedo, S. F., \& Hashim, H. (2019). Interactive ICT Language Games in Encouraging Active Learning among the Suburban ESL Learners. International Journal of Academic Research in Business and Social Sciences, 9, 674-684.

EF Education (2022). EF English Proficiency Index. https://www.ef.com/wwen/epi/regions/asia/malaysia/

Elliott, R., Fischer, C. T., \& Rennie, D. L. (1999). Evolving Guidelines for Publication of Qualitative Research Studies in Psychology and Related Fields. British Journal of Clinical Psychology, 38, 215-229. https://doi.org/10.1348/014466599162782

Govindasamy, P., Yunus, M. M., \& Hashim, H. (2019). Mobile Assisted Vocabulary Learning: Examining the Effects on Students' Vocabulary Enhancement. Universal Journal of Educational Research, 7, 85-92. https://doi.org/10.13189/ujer.2019.071911

Haja Mohaideen, M. S., Ismail, H. H., \& Rashid, R. A. (2020). The Use of Local Literary Texts as Reading Materials in English Language Classrooms: An Analysis of Teachers' Perspective. International Journal of Learning, Teaching and Educational Research, 19, 127-144. https://doi.org/10.26803/ijlter.19.11.8

Harmer, J. (2001). The Practice of English Language Teaching. Longman Group Ltd.

Harmer, J. (2015). The Practice of English Language Teaching (5th ed.). Pearson Longman.

Hashim, H. (2018). Application of Technology in the Digital Era Education. International Journal of Research in Counseling and Education, 2, 1-5. https://doi.org/10.24036/002za0002

Hashim, H., Md Yunus, M., Embi, A. M., \& Ozir, M. N. A. (2017). Mobile-Assisted Language Learning (MALL) for ESL Learners: A Review of Affordances and Constraints. Sains Humanika, 9, 45-50. https://doi.org/10.11113/sh.v9n1-5.1175

Herlina, H. (2014). Improving Students' Speaking Skill through Audio Visual Media at $4^{\text {th }}$ Grade of Labschool Elementary School East Jakarta. International Conference on Education and Language, 2, 87-96.

Ismail, H. H., Khairuddin, Z., \& Badi, J. A. B. (2019). Measuring Creativity and Risk-Taking Levels in an English Language Camp. International Journal of Innovation, Creativity and Change, 7, 218-236.

Kartini, M., Jubhari, R. R., \& Nasmilah. (2021). Exploring the Effect of Instagram Assisted 
Vlogging on Students' Speaking Proficiency. International Journal of Innovative Science and Research Technology, 6, 914-918.

Kurniawan, R., \& Susanti, F. (2019). Improving English Speaking Ability through Vlogging: An Innovative Breakthrough for Suburban Beginner Learners in English Community Muara Bungo. Journal of Language Education Development, 2, 224-231.

Mandasari, B., \& Aminatun, D. (2019). Uncovering Students' Attitude toward Vlogging Activities in Improving Students' Speaking Ability. Premise: Journal of English Education and Applied Linguitics, 8, 214-225. https://doi.org/10.24127/pj.v8i2.2241

Mart, C. T. (2012). Developing Speaking Skills through Reading. International Journal of English Lingusitics, 2, 91-96. https://doi.org/10.5539/ijel.v2n6p91

Marzuki, M. J., \& Nurpahmi, S. (2019). Using Video Blog in Teaching English. English Language Teaching for EFL Learners, 1, 13-23. https://doi.org/10.24252/elties.v1i1.7422

Mihăilescu, C. (2016). An Approach to George Orwell's 1984 via Lacan and Soja’s Thirdspacing. Journal of Romanian Literary Studies, No. 9, 123-127.

Moradi, Z., \& Talebi, S. H. (2014). Tge Effect of Pre-Speaking Strategies Instruction in Strategic Planning on Iranian EFL Students' Awareness as Well as Students' Fluency and Lexical Resources in Speaking. Procedia: Social and Behavioural Sciences, 98, 1224-1231. https://doi.org/10.1016/j.sbspro.2014.03.537

Nada, M. A. L. (2021). Vlogging towards Improving Students' Speaking Skills. EPRA International Journal of Research and Development (IJRD), 6, 711-722.

Nehe, B. M., Mayuni, I., \& Rahmat, A. (2018). Using Sociodrama in EFL Speaking Class: Related to Student Achievement. International Journal of Linguistics, Literature and Culture, 4, 44-52. https://doi.org/10.21744/ijllc.v4n4.262

Nunan, D. (1989). Designing Tasks for the Communicative Classroom. Cambridge University Press.

Parmawati, A., \& Inayah, R. (2019). Improving Students' Speaking Skill through English Movie in Scope of Speaking for General Communication. Journal of English Language Teaching in Indonesia, 7, 43-53.

Pazilah, F. N. P., Hashim, H., \& Yunus, M. (2019). Using Technology in ESL Classroom: Highlights and Challenges. Creative Education, 10, 3205-3212.

https://doi.org/10.4236/ce.2019.1012244

Rahi, S. (2017). Research Design and Methods: A Systematic Review of Research Pardigms, Sampling Issues and Instruments Development. International Journal of Economics \& Management Sciences, 6, Article No. 403.

Rahmah, U. S. (2018). Teaching Part of Speech and Word Groups as Units of Meaning in ESP Speaking Class. Journal of English for Academic and Specific Purposes, 1, 54-66. https://doi.org/10.18860/jeasp.v1i1.5245

Rahmawati, A., Harmanto, B., \& Indriastuti, N. R. (2018). The Use of Vlogging to Improve the Students Speaking Skill. Penerbitan Artikel Ilmiah Mahasiswa Universitas Muhammadiyah Ponorogo, 2, 87-95. https://doi.org/10.24269/ed.v2i1.96

Rodriges, S. (2006, September 5). 'A' in Exam, 'F' in Interview (p. N47). The Star.

Saputro, T. H., Tafsirudin, I. C., \& Farah, R. R. (2020). The Use of Vlog in Improving Students' Oral Language Production: A Case Study. English Education: Jurnal Tadris Bahasa Inggeris, 13, 135-158.

Selan, S. (2021, February 16). Sorry, What? Speaking English Still a Struggle for Many despite Mandatory Classes.

https://www.malaysianow.com/news/2021/02/16/sorry-what-speaking-english-still-a-st 
ruggle-for-many-despite-mandatory-classes/

Shahini, G., \& Shahamirian, F. (2021). Ways of Improving English Speaking Fluency via Two Productive Skills of Speaking and Writing: What Practical Tips Are Suggested? International Journal of Social Science Research, 3, 58-76.

Sun, Y. C. (2009). Voice Blog: An Exploratory Study of Language Learning. Language Learning \& Technology, 13, 88-103.

Tran, T. Q., \& Nguyen, L. T. T. (2019). Teaching English Grammar Communicatively: A Critical Look at the Roles of English Grammar in the EFL Context. In Proceeding of the International Conference on Language Teaching. Autonomy and Motivation for Language Learning in the Interconnected World (pp. 182-190).

Tuan, N. H., \& Mai, T. N. (2015). Factors Affecting Students' Speaking Performance at LE Thanh Hien High School. Asian Journal of Educational Research, 3, 8-23.

Tunku Mohtar, T. M., \& Swaran Singh, C. K. (2015). Developing the Speaking Skill among ESL Elementary Learners. The Asian Journal of English Language \& Pedagogy, 3, 161-180.

Wan Ibrahim, N. R., Kamarudin, M. F., \& Ramachandran, S. D. (2007). A Comparative Study of Chinese ESL Learners from Malaysia and the People's Republic of China in Their Pronunciation of /r/ \& /1/. In The Second Biennial International Conference on Teaching and Learning of English in Asia: Exploring New Frontiers (TELiA2) (pp. 1-16). Faculty of Modern Language, Universiti Utara Malaysia.

Watkins, J. (2012). Increasing Student Talk Time through Vlogging. Language Education in Asia, 3, 196-203. https://doi.org/10.5746/LEiA/12/V3/I2/A08/Watkins

Wong, H. T. C., \& Md Yunus, M. (2021). Board Games in Improving Pupils' Speaking Skills: A Systematic Review. Sustainability, 13, Article No. 8772. https://doi.org/10.3390/su13168772

Wulandari, E. (2019). Speaking Proficiency through Instagram Vlog. LLT Journal: A Journal on Language and Language Teaching, 22, 111-125. 